\title{
イソフルランがラット無酸素下分離肝細胞の エネルギー需給に及ぼす影響
}

岡山大学医学部麻酔 ·蘇生学教室 (指導 : 平川方久教授)

佐牟田健

(平成 6 年 8 月19日受稿)

Key words：イソフルラン, 分離肝細胞, エネルギーチャージ, 高エネルギーリン酸化合物

緒言

吸入麻酔薬は，臨床使用濃度で直接に酸素消 費とそれに共役する ATP 生成を抑制すると言 われている1!。一方, イソフルランは，無酸素下 でラット分離肝細胞の細胞内エネルギー需給バ ランスの指標の一つである (ATP/ADP) 比の 低下を抑制するという報告がある 2 (3). 即ちイソ フルランは in vitro において肝細胞のエネルギ 一需給に保護的に動く可能性が考之られ，臨床 においても肝血流が減少する様な状況下におい て肝障害を生じにくい可能性が考之られる。し かし今までの研究においてはイソフルランの濃 度の変化や無酸素の暴露時間の長さに関して詳 細な検討はなされていない。

本研究は, イソフルランの濃度の変化, 無酸 素状態の持続時間およびその後の再酸素化が, ラット分離肝細胞のエネルギー需給にどのよう な影響を及はす寸かについて肝細胞の ATP, ADP, AMP を測定し検討した.

\section{材 料と方法}

\section{1. 材料}

肝細胞は, 体重250-300 gの自由飲食水させた 雄性 Sprague Dawley 系ラットより分離した。 4-(2-hydroxyethyl)-1-piperazine ethane sulfonic acid (HEPES), bovine serum albumin (BSA), collagenase(Type 1), Percoll, tetrabutylammonium chloride, ATP, ADP, AMP およU゙ caffeine は, Sigma Chemical (St. Louis,

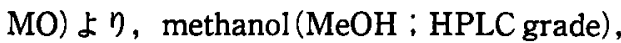

$70 \%$ perchloric acid $\left(\mathrm{HClO}_{4}\right)$ は, $\mathrm{EM}$ sceientific (Gibbstown, $\mathrm{NJ}$ ), potassium dihy drogenphosphate $\left(\mathrm{KH}_{2} \mathrm{PO}_{4} ;\right.$ HPLC grade), sodium chloride $は$, Fisher scientific (Fair Lawn, NJ) より, magnesium sulfate $\left(\mathrm{MgSO}_{4}\right.$. $\left.7 \mathrm{H}_{2} \mathrm{O}\right)$ は, Mallinchkrodt Chemical Works(St. Louis，MO）より購入した.

遠心分離機は, Sorvall RC-2B型に, SS-34型 ローターを装着して用いた，高速液体クロマト グラフィー（HPLC)は，CM4000型ポンプと SM5000型検出器 (LDC Analytical 社, Riviera Beach, FL)を装着し，分離カラムは, C-18逆相 カラム ( YMC 社, Morris Plains, NJ, Type A-302/S-5/120A/ODS)を用いた。気相のガス 組成の測定は，POET Infrared gas analyzer (Criticare Systems, Waukesha, WI) を用いた. 2. 方法

1）分離肝細胞の調製

ペントバルビタール $40-50 \mathrm{mg} / \mathrm{kg}$ 体重を腹腔内 に投与したのち開腹し，門脈に14ゲージ $(G)$ 血 管内カテーテルを挿入した後，肝下部で下大静 脈を切開した. 門脈カテーテルから，カルシウ ムを含まない $95 \%$ 酸素 $5 \%$ 二酸化炭素の混合気 で平衡させた $20 \mathrm{mM} の$ HEPES を含む, KrebsHenseleit 緩街液 $\left(37^{\circ} \mathrm{C}\right.$ ) (組成：6900mg/ 1 $\mathrm{NaCl}, 350 \mathrm{mg} / \mathrm{KCl}, 160 \mathrm{mg} / 1 \mathrm{KH}_{2} \mathrm{PO}_{4}, 290 \mathrm{mg} / \mathrm{l}$ $\mathrm{MgSO}_{4} \cdot 7 \mathrm{H}_{2} \mathrm{O}, 2090 \mathrm{mg} / 1 \mathrm{NaHCO}_{3}, \mathrm{pH} 7.4$ : 以後クレブス溶液) $40-50 \mathrm{ml} / \mathrm{min}$ で灌流を開 始した.クレブス溶液で10分間洗净した後。300 unit のcollagenase を $150 \mathrm{ml}$ のクレブス溶液に加 え12１4分灌流した．采らかくなった肝蔵を摘 
出し， $2 \% \mathrm{BSA}$ を合むクレブス溶液(アルブミ

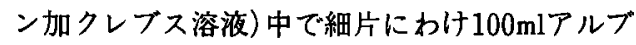
ミン加クレブス溶液に浸し, $500 \mathrm{ml}$ のフラスコ中 で $\mathrm{O}_{2} / \mathrm{CO}_{2}(95 / 5 \mathrm{vol} \%)$ 混合ガスを通気しなが ら $37^{\circ} \mathrm{C} て ゙ 15$ 分間ゆっくり振晹した後，ナイロン メッシュで滤過し，結合組織や血塊を除き細胞 懸濁液を得た。

この細胞懸濁液を, $12 \mathrm{ml} ゙$ 遠心管に分注し, それぞれに28mlの Percoll を加え, $4{ }^{\circ} \mathrm{C}, 10,000 \times$ $g$ で10分間遠沈した。次いで Percoll を除くた め上澄みを除去し底の肝細胞の層をアルブミン 加クレブス溶液にて毷濁し, $50 \times g$ で 2 分間室温 で遠沈し，底の肝細胞の層をアルブミン加クレ ブス溶液にて懸濁した。この懸濁液の一部をト リパンブルーで染色し, hemocytometer chamber を用いて生細胞を計測し, 90 95\%生存率の 2 〜 $4 \times 10^{8}$ コの肝細胞を含む稔濁液を調製した。

調製された肝細胞馝濁液から約 $12.5 \times 10^{6} \sqsupset の$ 細胞をアルブミン加クレブス溶液で総量 $2.5 \mathrm{ml}$ 希釈定容し， $25 \mathrm{ml}$ の球状の底をもつフラスコに 入れ，実験開始までは氷中で保存した。

フラスコは，ガスの出入りロとして 2 本の14 Gの針を貫通したゴムの蓋で覆い,プレインキ ユベーションとして $\mathrm{O}_{2} / \mathrm{CO}_{2}(95 / 5 \mathrm{vol} \%)$ 混合 ガスを $41 / \mathrm{min}$ で20秒間フラスコ内に通気し，フ ラスコ内の分離肝細胞懸濁液と平衡に達しめた 後ゴム蓋の $14 \mathrm{G}$ の針を抜き, $37^{\circ} \mathrm{C}$ の温水槽で 10 分間振盪後, 実験に供した。

2) 実験群の設定

実験は，次の(1)および(2)に分けて行った。

(1) 実 験 1

無酸素状態での分離肝細胞内高エネルギーリ

ン酸化合物に及ほすイソフルランの影響

方法 1）において最終的に調製された分離肝
細胞棃濁液のフラスコを用いて, $\mathrm{N}_{2} / \mathrm{CO}_{2}(95 /$ 5 vol\%）混合ガスをキャリアーガスとして1.4, $2.8,4.2 \mathrm{vol} \%$ のソフルランを加之, 肝細胞毷 濁液と平衡に達しめたのち 30 分間 $37^{\circ} \mathrm{C}$ の温水槽 で振晹した時点での ATP, ADP, AMP を HPLCにより測定した。計測は，それぞれ，4 回ずつ行った. 对照值は，イソフルランの投与 濃度を $0 \%$, すなわち，窒素下に 30 分間暴露し た時点の值をもってした. HPLCによるATP， ADP および AMP の測定方法は，3）におい て述べる。

(2) 実 験 2

無酸素状態に暴露した分離肝細胞を再酸素化 した場合，イソフルランがエネルギ一需給バラ ンスに及ばす影響について検討.

窒素ガスに90分間暴露することにより不可逆 的変化が生じるという事前のデータから, 窒素 ガス暴露の持続時間は, 不可逆的変化の起こら ない時間と, 不可逆的変化の起こる時間を, そ れぞれ, 30分間と90分間に設定し実験を行った。

表 1に示すように，30分間暴露をI群，90分 間暴露をII群としたＩ群およびI群は，さら に酸素の投与方法により，それぞれ，A， B， C群に分けた。

I-A群およびII-A群は， $\mathrm{N}_{2} / \mathrm{CO}_{2}(95 / 5 \mathrm{vol}$ \%) 混合ガスで分離肝細胞眯濁液の気相を置換 し, I-A群は30分間， II-A群は90分間， $37^{\circ} \mathrm{C}$ の温水槽で振湯後, $\mathrm{O}_{2} / \mathrm{CO}_{2}$ (95/5 vol\%) 混合 ガスで気相を置換した後，さらに，I-A群は 5 分間, II- A 群は 30 分間 $37^{\circ} \mathrm{C}$ の温水槽で振晹した. I-B群およびII-B群は, $\mathrm{O}_{2} / \mathrm{CO}_{2}(95 / 5 \mathrm{vol} \%)$ 混合ガスで分離肝細胞㗭濁液の気相を置換させ た後 I-B群は，35分間， II-B群は，120分間， $37^{\circ} \mathrm{C}$ の温水槽で振盪した。

\begin{tabular}{|c|c|}
\hline I（30分間暴露）群 & II（90分間暴露）群 \\
\hline A：イソフルランの投与 $(+$ ISO $)$, 無投与 & $\mathrm{A} ：$ イソフルランの投与 (+ISO), 無投与下 (-ISO) \\
\hline に30分間窒素暴露,そ0 & に90分間窒素暴露,その後さらに30分間酸素暴路 \\
\hline B：イソフルランの投与, 無投与下に35分間酸素暴露 & $\begin{array}{l}\mathrm{B} \text { ：イソフルランの投与, 無投与下に } 120 \text { 分間酸素暴 } \\
\text { 蕗 }\end{array}$ \\
\hline C：イソフルランの投与と無投与下に30分間窒菜暴露 & $\mathrm{C}$ ：イソフルランの投与, 無投与下に 90 分間窒素暴露 \\
\hline
\end{tabular}


I-C群およびII-C群は, $\mathrm{N}_{2} / \mathrm{CO}_{2}(95 / 5$ vol \%)混合ガスで分離肝細胞愻濁液の気相を置換 させた後 I-C群は30分間, II-C群は90分間, $37^{\circ} \mathrm{C}$ の温水槽で振晹した。

イソフルラン投与群は,カッパーチトル気化 器にて上記それぞれの混合気をキャリアーガス として1.4\%のイソフルランを加えた.

実験 1 ，実験 2 は，ともにインキュベーショ ン終了時点で, 水冷 $2 \mathrm{M} \mathrm{HClO}_{4} 0.5 \mathrm{ml}$ 肝細胞 懸濁液に投与した。この照濁液を遠沈し，透明 な上澄みを氷中で $2 \mathrm{M} \mathrm{KOH}$ を用いて中和し， 過剩の過塩素酸カリウム塩を沈殿させた，その 上澄みをフィルターで滤過し，ヌクレオチドを

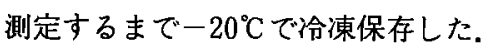

3) ATP, ADP および AMP の测定方法お よび総ヌクレオチドとエネルギーチャー ジの算出法

$\mathrm{ATP}, \mathrm{ADP}$ おび AMP は, カフェインを internal standard として HPLCにて分離分析 した。試料からのそれぞれのヌクレオチドの分 離は，C-18逆相カラムを用い,カラムからの溶 出は表 2 に示す, A液と B 液のグラディエント により行った.

ATP, ADP およU゙ AMP の未知の濃度の決 定は, 濃度を知りたい物質の面積と internal standardであるカフェインの面積の比を，標準 溶液を分析することで決定した. ヌクレオチド の濃度単位は, 錅濁液中の $\mu \mathrm{M}$ で求めた. 工ネ ルギーチャージは, (ATP+1/2ADP)/(ATP+ $\mathrm{ADP}+\mathrm{AMP})$ の式を用いた4).

4) 統計学的検定

統計学的解析は，一元または二元配置分散分 析法, Scheffe's test 㧍よび paired Student's $t$ -test を用いて比較し，P<0.05を有意差有りと した.

表 2 HPLC の溶離組成とグラディエント方法

\begin{tabular}{|c|c|c|c|}
\hline $\begin{array}{l}\text { 組 } \\
\text { 成 }\end{array}$ & \multicolumn{3}{|c|}{ A液: $30 \mathrm{mM} \mathrm{KH}_{2} \mathrm{PO}_{4}+8 \mathrm{mM}\left[\left(\mathrm{CH}_{3}\left(\mathrm{CH}_{2}\right)_{3}\right)_{4} \mathrm{~N}\right] \mathrm{Cl}$} \\
\hline グエ & $0-2$ 分 & $0 \%$ & $\mathrm{~B}$ 液 \\
\hline & $2-15$ 分 & $50 \%$ & $\mathrm{~B}$ 液 \\
\hline イト & 15-30分 & $50-65 \%$ & $\mathrm{~B}$ 液 \\
\hline
\end{tabular}

結果

1. 実 験 1

無酸素状態での分離肝細胞内高エネルギーリ ン酸化合物に及ぼすイソフルランの影響の結果 は，図1に示すとおりである。

イソフルラン浱度が1.4, 2.8, 4.2\%での ATP の濃度は, 各々对照（イソフルラン濃度 $0 \%$ ） 時のATPの濃度に比し有意に増加し， $2.8 \%$ の 時が最大であった。

$\mathrm{ADP}$ の濃度は, イソフルランのどの濃度にお いても有意な変化を示さなかった。

AMP の濃度は, イソフルランの投与により， 对照に比較して有意に減少した。

2. 実 験 2

無酸素状態に暴露した分離肝細胞を再酸素化 した場合、イソフルランがエネルギー需給バラ ンスに及ばす影響の結果をI (30分間暴露) 群 は図 2 に，II（90分間暴露）群は図 3 に示す。

a) I (30分間暴露) 群

$\mathrm{I}$-A群においてはイソフルラン投与群(困 2 $\mathrm{A} の+\mathrm{ISO})$ と無投与群（一ISO）においてエネ ルギーチャージ, ATP, ADP, AMP, すべて のパラメーターについて有意差はなく，イソフ ルラン投与の影響はみられなかった。

I - B 群 (困 2のB) ではイソフルランの無投 与群(-ISO)に比して, イソフルラン投与群 $(+$ ISO)においては, ADP と AMP は若干増加 し，ATPは滅少したエエネルギーチャージは， 有意に減少した。

I-C群（図2のC）において+ISO 群は, 一 ISO 群に比較してエネルギーチャージおよU゙ ATP は有意に増加し, AMP は有意に減少した. I 一A群は I-B群とすべてのパラメーターにおい て有意差は見られなかった。

b）II (90分間暴露) 群

II-A群 (図 3 のA) では, +ISO群でーISO群 に比較して ATP, ADP, 総ヌクレオチド濃度, エネルギーチャージは，有意に増加した。

II-B群（図 3 のB）の+ISO 群は, -ISO 群 に比較して，エネルギーチャージが有意に減少 した。

II-C群(図 3 のC)の, +ISO 群の ATP は, 一 


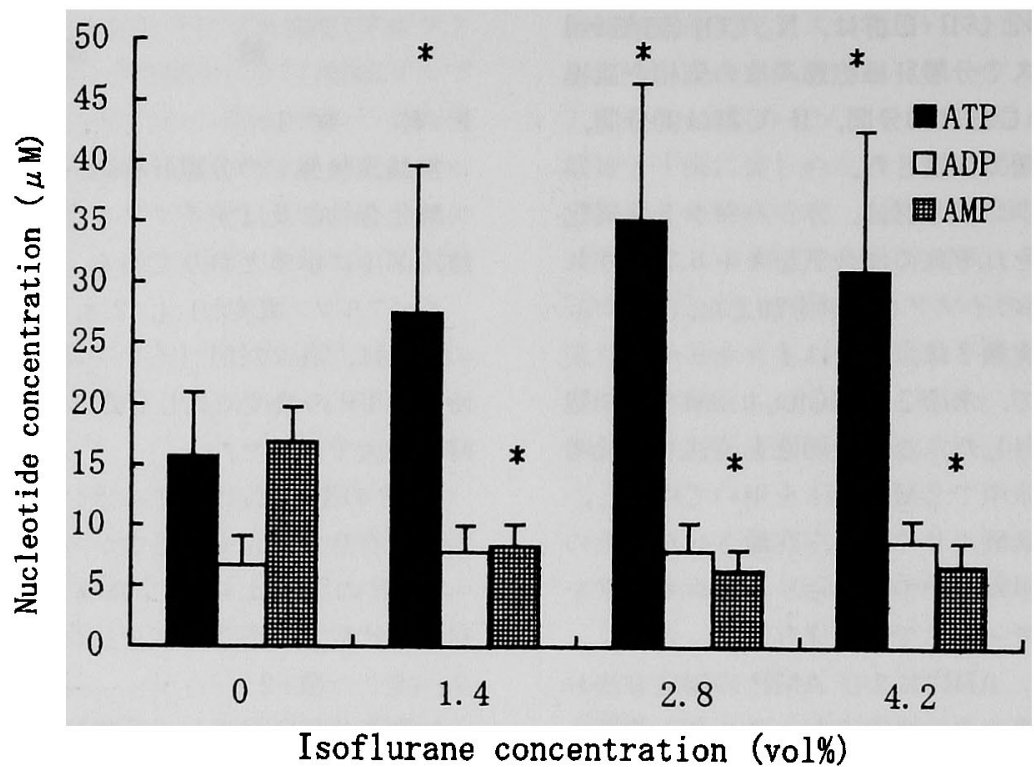

図 1 ラット分離肝細胞の高エネルギーリン酸化合物に対するイソフルランの影響 ラット分離肝細胞を, 30分間イソフルランを1.4, 2.8,4.2\%の濃度で無酸素暴露下に投与したときの ATP,

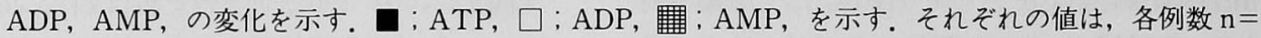
4 の平均值十標準偏差を示し, 単位は, $\mu \mathrm{M}$ である.イソフルランの投与濃度の $0 \%$ を対照とした.一*一； 対照 $(0 \%)$ 時の值に対する有意差 $(\mathrm{P}<0.05)$ を示す.

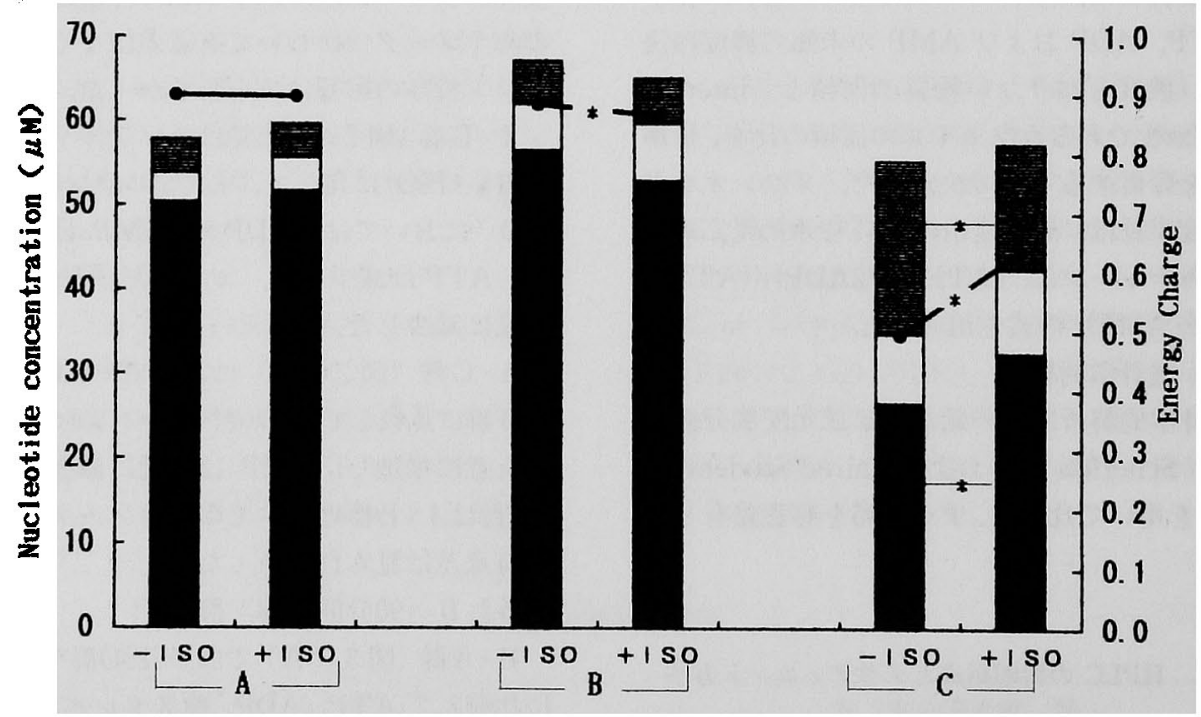

区 2 ラット分離肝細胞の I (30分間暴露) 群におけるイソフルランの影響

ラット分離肝細胞に窒素ガス暴露30分後酸素暴露 5 分 $\mathrm{A}$, 酸素暴露35分 $\mathrm{B}$, 窒素ガス暴露35分 $\mathrm{C}$ の各条件 下にイソフルランを投与した場合 (+ISO) と投与しなかった場合 (-ISO)の総ヌクレオチド濃度 $(\mathrm{ATP}+$

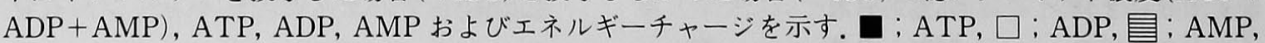
○：エネルギーチャージを示す. ATP, ADP および AMPの単位は $\mu \mathrm{M}$ である.それぞれの值は, 各 例数 $\mathrm{n}=8$ の平均值である。一－； 2 群間における有意差 $(\mathrm{P}<0.05)$ を示す. 


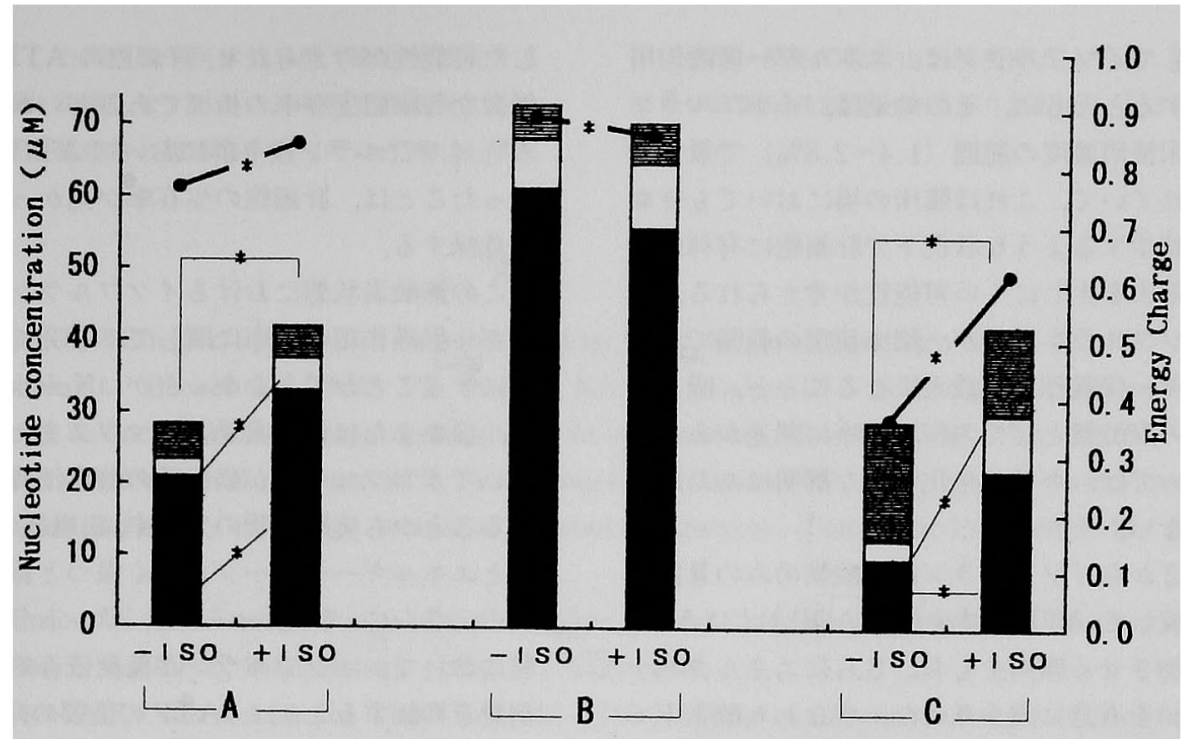

図 3 ラット分離肝細胞の II（90分間暴露）群におけるイソフルランの影響

ラット分離肝細胞に窒素ガス暴露 90 分後酸素暴露 30 分 $\mathrm{A}$, 酸素暴露120分 $\mathrm{B}$, 窒素がス暴露 90 分 $\mathrm{C}$ の各条 件下にイソフルランを投与した場合 (+ISO), 投与しなかった場合 (-ISO)の総ヌクレオチド濃度, ATP, $\mathrm{ADP}, \mathrm{AMP}$ おびエネルギーチャージを示す、ロ；ATP， $\square ； \mathrm{ADP}$, 冒；AMP，；エネルギーチ ヤージを示す. ATP, ADP, AMPの単位は, $\mu \mathrm{M}$ である. それぞれの值は, 各例数 $\mathrm{n}=8$ の平均值で ある。 一*ー； 2 群間における有意差 $(P<0.05)$ を示す。

ISO 群の 2 倍以上に, 総ヌクレオチド濃度, エ ネルギーチャージおよび ADP は, 有意に増加 した.

図 3 のII-A群では，II-B群に比較してエネ ルギーチャーシ，ATPおよび総ヌクレオチド濃 度は有意に減少した.

c） I (30分間暴露) 群と II (90分間暴露) 群 酸素のみの暴露では図 2 の35分と図 3 の120分 の間では全てのパラメーターで有意な差は認め られなかった。

図 $3 \mathrm{C}$ の-ISO 群の90分間の窒素ガス暴露で は図 $2 \mathrm{C}$ の-ISO 群の30分間掌素ガス暴露に比 較して ATP, ADP, AMP, 総ヌクレオチド濃 度およU゙エネルギーチャージは，それぞれ，有 意に減少した。

\section{考察}

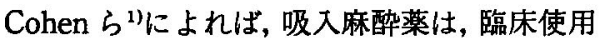
濃度で直接にミトコンドリアの呼吸銷を抑制し， ATP 生成を抑制するという。一方，無酸素下で は, イソフルランがラット分離肝細胞の ATP/ ADP の減少を抑制するという報告2,3)がある。
本研究では，結果としては前回の研究と矛盾 しなかったが，エネルギー需給バランスの指標 としては著者らが前回用いた ATP/ADP 比より AMP を考虑している点でより詳細なエネルギ 一チャージを用いた4.

ATP の分解が一旦 AMP を越えて進むと再 び酸素化してもATPに戻るのには時間を要す るため, ATP 量は䋓ヌクレオチド濃度により推 測することができる5).従って本研究では, ATP 量の上限として総邓クレオチド濃度を用いた。

イソフルランの成人の minimum alveolar concentration (MAC)は，1.15\%といわれてい ることから，本研究の実験 2 ではイソフルラン の投与量は，臨床麻醉でよく用いられる濃度で ある1.25MAC すなわち1.4\%とした。

本研究における窒素ガス暴露下での ATP 量 は, イソフルランの投与量が, $2.8 \%$ まで量依存

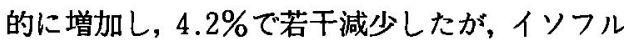
ランの投与によって細胞内 ATP 量が増加する ことが示された(図 1). 細胞内に ATPゃADP が残存または蓄積されることを、「エネルギー保 護作用」と考えるならば，無酸素下分離肝細胞 
に対してイソフルランは, エネルギー保護作用 を有するとともに，その効果は，イソフルラン の臨床使用濃度の範囲 $(1.4 \sim 2.8 \%)$ で最も発 揮されていて，これは臨床の場においても肝血 流が減少するような状況下で肝細胞に有利に働 き肝障害を生じにくい可能性が考えられる.

イソフルラン濃度が, 臨床使用の範囲で, エ ネルギー保護作用が最大になることと，吸入麻 酔薬の麻酷薬としての作用機序に関連があるか については, 今後の生化学的な解明にまたねば ならない.

図 2 からイソフルランは, 酸素のみの暴露時 に比較して, ATP を減少させ, ADP およびAMP を増加させる傾向をもち，さらにエネルギーチ ヤージを有意に減少させた。すすなわち酸素下で はイソフルランは肝細胞のエネルギー需給バラ ンスをむしろ損なう方向に働く，Cohen らの報 告”によれば,酸化的リン酸化による ADPから ATPへの転換を吸入麻酔薬は，抑制するといい, 酸素下でのイソフルラン投与群におけるエネル ギーチャージの減少はこのためであると考えら れる.

次に, 30分の窒素がス暴露でイソフルランは, エネルギーチャージおよび ATP を有意に高く 保つのにもかかわらず, その後 5 分の酸素暴露 によりその作用が見られなくなったこと，35分 間の酸素暴露だけの群と30分間の窒素がス暴露 後に 5 分間再酸素化を加之た群の間では，30分 間での窒素がス暴露は, 肝細胞に不可逆的な影 響を及はささなかったためと考えられた。

図3に見られるように，長い時間の無酸素へ の暴露実験において, II-A (再酸素化), II-C (窒素暴露)いずれの群においてもイソフルラン 投与によりエネルギーチャージは, 高く保たれ, それぞれにエネルギー保護作用が認められた。 両群ともに対照となる酸素暴露群より紷ヌクレ オチド量がいずれも有意に減少した。このこと は，90分間の窒素がス暴露により，分離肝細胞 に不可逆的な変化が生じたと考えられた。

しかし再酸素化群, 窒素ガス暴露群のいずれ の群においてもイソフルラン投与群において, ATP 量, 綕ヌクレオチド量が多かったことは, イソフルランが不可逆的な変化一の進行を抑制
した可能性が考えられた. 肝細胞の ATP 量は, 鋭敏な肝細胞生存率の指標であるといわれてい る6. イソフルラン投与群において ATP 量が多 かったことは，肝細胞の生存率が高かったこと を意味する。

この無酸素状態におけるイソフルランのエネ ルギー保護作用の機序に関して本研究では明ら かにすることができなかったが, Newberg ら゙ は，虚血または低酸素暴露のマウスまたは犬に おいてイソフルランが脳組織の酸素消費を抑制 することから実験動物の生存率, 脳組織の ATP 量とエネルギーチャージを高く保つと報告して いる.さらに, Becker ら ${ }^{8)}$ は，ラット分離肝細 胞において，イソフルランが濃度依存的に酸素 消費を抑制することは，ATPの需要の抑制によ るものであると報告している.

今回の研究においては, 窒素がス暴露の肝細 胞においてイソフルラン投与群で非投与群に比 して AMP 量が有意に少ないことからイソフル ランは, 無酸素下において AMP 生成を抑制し，

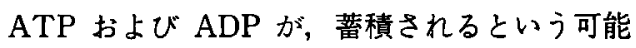
性が考えられた。しかしいかにして AMP の生 成が抑制されるのか?, AMP 生成の抑制が ATP を増加させることにつながるのか？，この可能 性については今後の研究により明らかにしてい かねばならない。

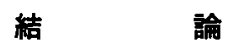

ラット分離肝細胞を用いてイソフルランの肝 細胞のエネルギー需給に及ばす影響について検 討し以下の結果を得た。

1. イソフルランは, 酸素下においてはラッ 卜分離肝細胞のエネルギーチャージを減少させ た.

2 . イソフルランは，無酸素下においてラッ 卜分離肝細胞の ATP およびエネルギーチャー ジを高く保ち，その作用はイソフルランの浱度 が2.8\%の時に最大であった。

3. イソフルランは, 無酸素下においてラッ ト分離肝細胞のエネルギー需給を保護すると考 えられた。

稿を終えるに臨み、終始瑟切なるご指導，御校閲 
を賜りました岡山大学医学部麻酔・镍生学教室平川 方久教授に深謝します．また，本研究の遂行に当た

$\eta$ ，賈重な御助言と御協力をいただいた岡山大学医
学部麻酔・蘇生学教公山田輝夫博士, 平山 徽博士 ならびに岡田尚起博士に心より御礼申し上げます。

\section{文献}

1) Cohen PJ : Effect of anesthetics on mitochondrial function. Anesthesiology (1973) 39, 153-163.

2) Pathak BL, Becker GL, Reilly PJ, Hanson KA and Landers DF : Isoflurane partially preserves energy balance in isolated hepatocytes during in vitro anoxia. Anesth Analg (1991) 72, 571-577.

3) Samuta T, Becker GL, Pohorecki R, Armstrong K and Landers DF : Cyclosporine, isoflurane, and oxygenation effects on energy balance in isolated hepatocytes. Transplant Proc (1993) 25, 18471849.

4) Atkinson DE : The energy charge of the adenylate pool as a regulatory parameter. Interaction with feedback modifiers. Biochemistry (1968) 7, 4030-4034.

5) Vincent MF, Van den Berghe $G$ and Hers HG : The pathway of adenine nucleotide catabolism and its control in isolated rat hepatocytes subjected to anoxia. Biochem J (1982) 202, 117-123.

6) Frank AM, Ralf MW, Andries SK and Noordhoek J : Depletion of ATP but not of GSH affects viability of rat hepatocytes. Eur J Pharmacol (1992) 228, 229-236.

7 ) Newberg LA and Michenfelder JD : Cerebral protection by isoflurane during hypoxemia or ischemia. Anesthesiology (1983) 59, 29-35.

8 ) Becker GL, Miletich DJ and Albrecht RF : Halogenated anesthetics increase oxygenconsumption in isolated hepatocytes from phenobarbital-treated rats. Anesthesiology (1987) 67, 185-190. 


\author{
佐车田健 \\ Effect of isoflurane on energy status \\ of isolated hepatocytes \\ Takeshi Samuta \\ Department of Anesthesiology and Resuscitology, \\ Okayama University Medical School, \\ Okayama 700, Japan \\ (Director : Prof. M. Hirakawa)
}

We investigated the variation in the protection of energy status by isoflürane in isolated hepatocytes with the isoflurane dose, duration of anoxia, and reoxygenation by measurements of ATP, ADP, and AMP, in the cells. During $30 \mathrm{~min}$ of anoxia, in the presence of 1.4, 2.8, 4.2\% isoflurane the ATP concentration was more than that with $0 \%$ isoflurane. With a $30-35$ min incubation in the presence of $\mathbf{1 . 4 \%}$ isoflurane, there was a modest decrease in energy charge during anoxia, partially prevented by isoflurane and completely reversed by reoxygenation, and no decrease in the total adenine nucleotide. With a 90-120 min incubation, isoflurane partly prevented the decreases in both energy charge and total adenine nucleotide during both anoxia and reoxygenation. We conclude that at doses in the clinical range, isoflurane partially protected isolated hepatocytes against decreases in both energy charge and total adenine nucleotide occurring either during short or long anoxia. 